\title{
環境評価点を用いた銀の大気腐食に対する寿命評価
}

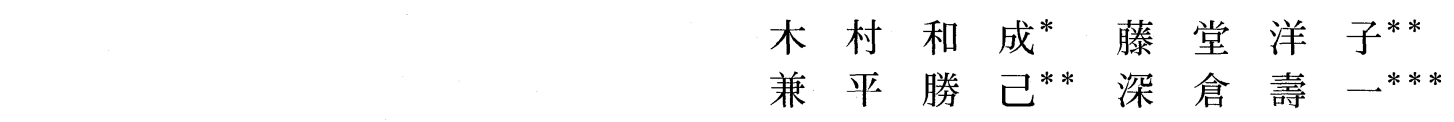

\section{Atmospheric Corrosion Life Assessment of Silver by Means of Environmental Indices}

by

Kazushige Kimura ${ }^{*}$, Yoko Todo ${ }^{* *}$, Katsumi KaneHIRA ${ }^{* *}$ and Juichi FuKakuRA ${ }^{* * *}$

\begin{abstract}
Atmospheric corrosion test data for silver were analyzed which were obtained in various sites in Japan. A new corrosion life assessment method was developed. The method took into account the interactive effect of multiple environmental factors on the decrease in metal weight during corrosion tests. The simple and practically useful formula for corrosion life prediction was established in terms of environmental indices and the formula could enable the evaluation of time dependent loss of metal weight based on the environmental assessment.
\end{abstract}

Key words : Atmospheric corrosion, Environmental index, Weibull distribution

\section{1 緒言}

電気・電子機器は長期間使用中に劣化し, 所定の性能 を発揮しなくなったり, 故障して使用不可能になること がある. 電気・電子機器は銅，アルミニウム，銀，鉄な ぞの金属からなる要素部品で構成され, 劣化の原因は金 属の腐食に起因することが多い. 電気・電子機器にその 役割を十分果たさせるには，適切な時期に適切な処置を 講じることが必要であり，金属の大気腐食に対する寿命 評価法の構築が望まれる。そこで，報告者らは配線材料 として多用される銅について, 大気環境中での多数の腐 食試験データを分析し; 環境評価点を用いて腐食減量の 時間依存性を定式化した. 1 .

本報では銅 ${ }^{1)}$ と同様に電気・電子機器に多用される銀 (以下 $\mathrm{Ag}$ ）について, 大気中での腐食に対する寿命評価 法を検討した。

\section{2 試 験 方 法}

$\mathrm{Ag}$ 板を国内 6 ケ所 $(\mathrm{A}$ : 首都圈郊外, B : 地熱発電所, $\mathrm{C}$ ：アンモニア製造工場, D：塩素製造工場, E, F：沿 海都市）の試験サイト屋内外に 1 年間暴露し, 併せて大 気環境を測定した。

\section{$2 \cdot 1$ 大気腐食試験（暴露試験）}

$\mathbf{2} \cdot \mathbf{1} \cdot \mathbf{1}$ 試験片形状と暴露方法 大気暴露試験法 ${ }^{2)}$ に準じ, $100 \mathrm{~mm} \times 50 \mathrm{~mm} \times 1 \mathrm{mmt}$ の試験片を約 45 度傾 斜させて試験架台に取付け, 各暴露試験サイトの屋内外 に設置した。

$\mathbf{2} \cdot \mathbf{1} \cdot \mathbf{2}$ 腐食減量の測定 試験片は試験前に脱脂処 理し十分乾燥した後, 初期重量を秤量した. $3 ， 6 ， 12$ ケ
月の試験終了後に，その間に生成した腐食生成物を $10 \%$ 硫酸中で $2 \sim 3$ 分間洗浄しブラシで除去して十分乾燥し た後, 残存重量を科量した. 秤量の精度は $0.1 \mathrm{mg}$ である.

\section{$2 \cdot 2$ 環境測定}

$\mathbf{2} \cdot \mathbf{2} \cdot \mathbf{1}$ 測定項目 Table Iの環境区分表中の各因 子を測定した．環境区分表は環境因子の量をクラス分け し，各種金属の腐食への影響の程度を環境評価点として

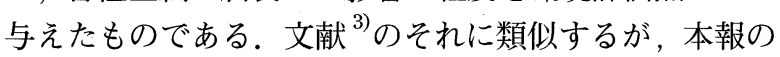
試験とは別に，国内数百箇所での環境測定と各種金属の 暴露試験の結果を基に設定したものである.1

$\mathbf{2} \cdot \mathbf{2} \cdot \mathbf{2}$ 測定方法 屋外では暴露架台近傍に設置し た百葉箱中で，また屋内では試験片設置場所で，腐食減 量の測定にあわせて $3 ， 6 ， 12$ ケ月後に行なった．各環 境因子の測定方法は $\mathrm{Cu}$ のそれ ${ }^{1)}$ と同じである.

\section{3 試 験 結 果}

Fig. 1 に試験期間毎に全試験サイトでの $\mathrm{Ag}$ の腐食減 量 $W$ と式 (1) で算出した合計環境評価点 $e$ との関係を 示した。

$$
e=\Sigma \kappa_{i} \cdot e_{i}
$$

ここで, $e_{i}$ は各試験サイトでの環境測定結果をTable I の区分に当てはめて決定した各環境因子それぞれの環境 評価点, $\kappa_{i}$ は合計環境評価点 $e$ への重み係数であり, こ こでは 1 とした. $\mathrm{H}_{2} \mathrm{~S}$ と $\mathrm{SO}_{2}$ はいずれも $\mathrm{SO}_{3}$ として検出 されるので，検出された吸着物が $\mathrm{H}_{2} \mathrm{~S}$ と $\mathrm{SO}_{2}$ のいずれに よるものかは $\mathrm{Ag}$ 板と共に設置した $\mathrm{Cu}$ 板の腐食生成物 の色で判定した。腐食生成物が黒色であれば $\mathrm{H}_{2} \mathrm{~S}$ ，褐色 であれば $\mathrm{SO}_{2}$ である。

$\dagger \quad$ 原稿受理 平成 12 年 11 月 2 日 Received Nov. 2, 2000

* 正 会員 (財) ファインセラミックセンター試験研究所 テ 456-8587 名古屋市熱田区六野, Res. and Development Laboratory, Japan Fine Ceramics Center, Atuta-ku, Nagoya, 456-8587

** (侏)東芝電力・産業システム技術開発センター テ183-8511 府中市東芝町, Power and Industrial Systems R \& D Center, Toshiba Co., Toshiba-cho, Fuchu, 183-8511

*** 正会員 (株)東芝電力・産業システム技術開発センター † 230-0045，横浜市鶴見区末広町，Power and Industrial Systems R\&D Center, Toshiba Co., Tsurumi-ku, Yokohama, 230-0045 
Table I. Classification of environment.

\begin{tabular}{|c|c|c|c|c|c|c|c|c|c|c|c|}
\hline \multirow{2}{*}{\multicolumn{2}{|c|}{ Environmental factor }} & & & \multicolumn{2}{|l|}{ III } & \multicolumn{2}{|c|}{ III } & \multicolumn{2}{|c|}{$\mathrm{IV}$} & \multicolumn{2}{|c|}{$\mathrm{V}$} \\
\hline & & Range & Point & Range & Point & Range & Point & Range & Point & Range & Point \\
\hline Average temperature per year $\left({ }^{\circ} \mathrm{C}\right)$ & $\mathrm{A}$ & $\leqq 20$ & 1 & $\leqq 25$ & \begin{tabular}{|l|}
2 \\
\end{tabular} & $\leqq 30$ & 4 & $\leqq 35$ & 8 & $>35$ & 12 \\
\hline Average humidity per year (\%RT) & $\mathrm{B}$ & $\leqq 60$ & 1 & $\leqq 65$ & 6 & $\leqq 70$ & 12 & $\leqq 80$ & 24 & $>80$ & 36 \\
\hline $\mathrm{S} \mathrm{O}_{2}(\mathrm{mdd})$ & C 1 & $\leqq 0.02$ & 1 & $\leqq 0.05$ & 4 & $\leqq 0.2$ & 8 & $\leqq 0.5$ & 16 & $>0.5$ & 24 \\
\hline $\mathrm{H}_{2} \mathrm{~S}(\mathrm{mdd})$ & C 2 & $\leqq 0.02$ & 1 & $\leqq 0.05$ & 6 & $\leqq 0.2$ & 12 & $\leqq 0.5$ & 24 & $>0.5$ & 36 \\
\hline $\mathrm{NO}_{2}$ (mdd) & C 3 & $\leqq 0.02$ & 1 & $\leqq 0.05$ & 3 & $\leqq 0.2$ & 6 & $\leqq 0.5$ & 12 & $>0.5$ & 18 \\
\hline $\mathrm{C}^{-}$(mdd) & C 4 & $\leqq 0.02$ & 1 & $\leqq 0.05$ & 7 & $\leqq 0.2$ & 14 & $\leqq 0.5$ & 28 & $>0.5$ & 42 \\
\hline $\mathrm{NH}_{4}^{-}$(mdd) & C 5 & $\leqq 0.02$ & 1 & $\leqq 0.1$ & 3 & $\leqq 1.0$ & 6 & $\leqq 10$ & 12 & $>10$ & 18 \\
\hline Air-borne salt particle (mdd) & $\bar{D}$ & $\leqq 0.01$ & 1 & $\leqq 0.03$ & 5 & $\leqq 0.1$ & 10 & $\leqq 0.3$ & 20 & $>0.3$ & 30 \\
\hline Distance from shore (km) & & $>2.0$ & 1 & $\geqq 1.5$ & 5 & $\geqq 1.0$ & 10 & $\geqq 0.5$ & 20 & $<0.5$ & 30 \\
\hline
\end{tabular}

\section{4 考察}

\section{$4 \cdot 1$ 腐食減量 $W$ と合計環境評価点 $e$ の関係}

Fig. 1 から, $\mathrm{Cu}^{1)}$ と同様, いずれの試験期間でも $\mathrm{Ag}$ の腐食減量 $W$ (図中○) は合計環境評価点 $e$ の増加に対 して二次関数的に増加すること, 試験サイト B の腐食減 量 $W$ （図中）は他の試験サイトのそれに比べて大きい ことがわかる．また，当然のことながら試験期間が長い
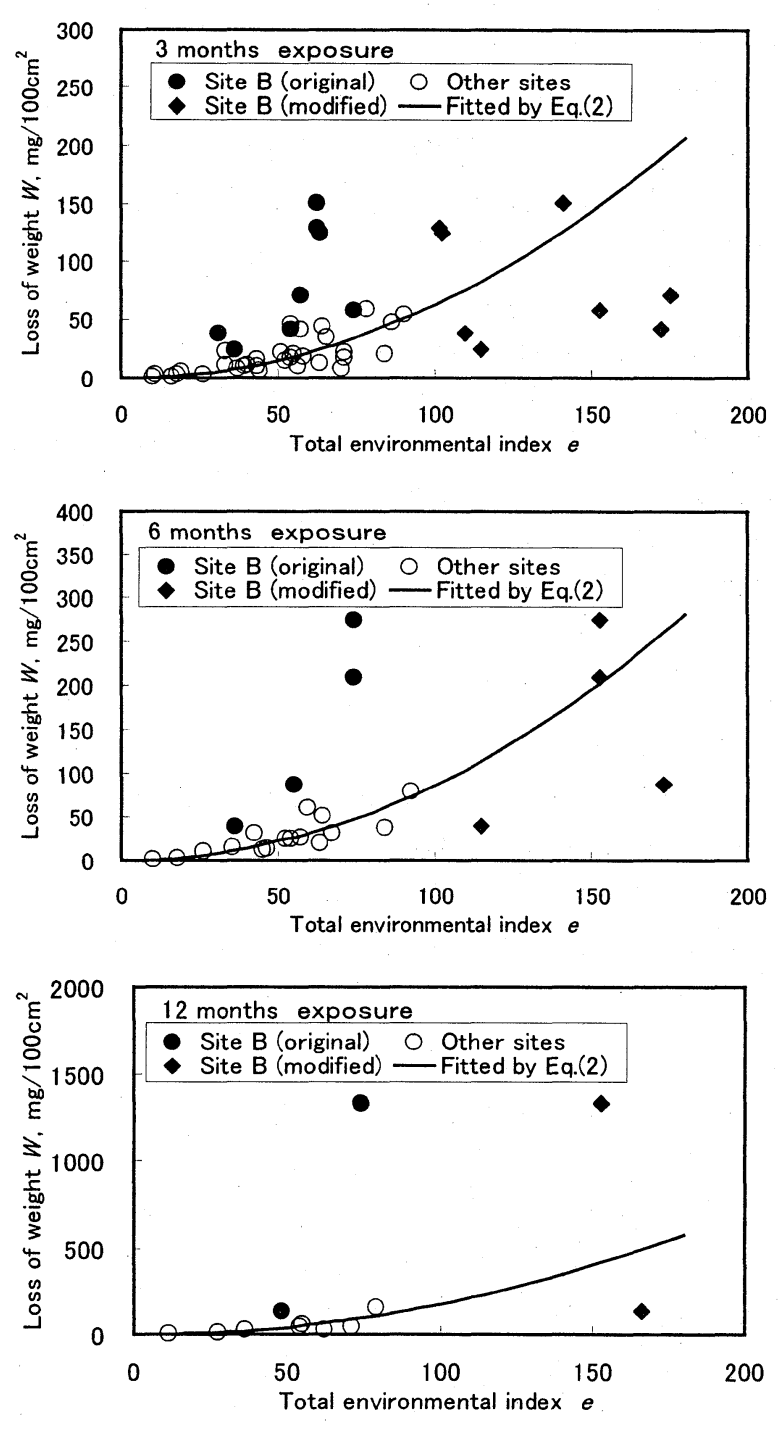

Fig. 1. Correlation between total environmental index and loss of weight.

\section{ほど腐食減量 $W$ は大きい。}

合計環境評価点 $e$ は全て環境評価点 $e_{i}$ が 1 の時に最小 值 8 となる. この時, 腐食減量 $W=0$ と考えると, 腐食 減量 $W$ と合計環境評価点 $e$ の関係は試験期間毎に式 (2) で近似することができる.

$$
W=\alpha \cdot(e-8) \cdot(e+8)
$$

$\alpha$ は近似係数であり暴露日数のみに依存する. Fig. 1 に は試験サイト $B$ 以外の試験サイトでで得たデータ（図中 ○）を式 (2)で近似した結果も線困で示した。

合計環境評価点 $e$ は各種環境因子を含む大気の有害性 の複合的な効果を表すもので，これを用いると $\mathrm{Ag}$ の大 気中で腐食減量 $W$ は, サイト $B$ を除き, 試験サイトに よらず統一的に表すことができる。

\section{$4 \cdot 2$ 硫化水素 $\left(\mathrm{H}_{2} \mathrm{~S}\right)$ の環境評価点に対する重み係数}

上記のように, 試験サイト $B$ のデータは他の試験サイ トのそれに対して成立する式 (2) の関係からはずれ，式 (1) で $\kappa_{i}=1$ とした場合の合計環境評価点 $e$ から予想され る以上に腐食が進行している.

試験サイト $B$ の環境的な特徵は当試験サイトが地熱発 電所で, $\mathrm{H}_{2} \mathrm{~S}$ の環境評価点は $12 \sim 36$ であり，他の試験 サイトではそれが 1 であるのと比べ圧倒的に大きいこと である. 即ち, $\mathrm{H}_{2} \mathrm{~S}$ が含まれる場合, 式 (1) の $\mathrm{H}_{2} \mathrm{~S}$ に対 する重み係数 $\kappa_{H 2 S}$ は 1 よりも大きく, 結果として合計環 境評価点 $e$ も大きなると考えられる。 そこで, 以下， 式 (1) 中の $\mathrm{H}_{2} \mathrm{~S}$ の環境評価点 $e_{H 2 S}$ に対する重み係数 $\kappa_{H 2 S}(\neq 1)$ について検討する.

$\mathrm{H}_{2} \mathrm{~S}$ の環境評価点 $e_{H 2 S}$ に重み係数 $(\neq 1)$ を考慮した 場合の合計環境評価点を $e_{o}$ とすると, $e\left(\kappa_{H 2 S}=1\right.$ の場 合の合計環境評価点) との関係は式 (3) となる.1)

$$
\left(e-e_{H_{2} S}\right)+\kappa_{H_{2} S} \cdot e_{H_{2} S}=e_{0}
$$

左辺第 1 項は $\mathrm{H}_{2} \mathrm{~S}$ 以外の環境因子の環境評価点の総和, 第 2 項は重み係数 $\kappa_{H 2 S}(\neq 1)$ を加味した $\mathrm{H}_{2} \mathrm{~S}$ の環境評 価点である。これらを合計したものが右辺の $\mathrm{H}_{2} \mathrm{~S}$ の環境 評価点に重み係数 $\kappa_{H 2 S}(\neq 1)$ を加味した場合の合計環 境評価点 $e_{0}$ である. 換言すれば, $e_{0}$ は $e$ に $e\left(=\left(\kappa_{H 2 S}-\right.\right.$ 1)・ $\left.e_{H 2 S}\right)$ を加算したものである.

Fig. 1 で, 試験サイトBの全データの合計環境評価点 $e$ と腐食減量 $W$ の組み合わせ $(e, W)$ において, $e$ に $\Delta e\left(=\left(\kappa_{H 2 S}-1\right) \cdot e_{H 2 S}\right)$ を加算したもの, 即ち $(e+\Delta e, W)$ $=\left(e+\left(\kappa_{H 2 S}-1\right) \cdot e_{H 2 S}, W\right)=\left(e_{o}, W\right)$ が式 (2) で近似でき 
るように $\kappa_{H 2 S}$ を設定すれば，これが所定の $\mathrm{H}_{2} \mathrm{~S}$ の環境評 価点に対する重み係数となる. この時, 重み係数を加味 した試験サイト $B$ の合計環境評価点 $e_{0}$ と腐食減量 $W$ の 全データの重心座標 $\left(e_{\text {oave }}, W_{\text {ave }}\right)$ は式 (2) を満たすので $W_{\text {ave }}$ に対応する $e_{\text {oave }}$ を式 (2) から求めると, これが $e+$ $\left(\kappa_{H 2 S}-1\right)+e_{H 2 S}$ の平均值である. 即ち, 式 (4) の関係を 得る.

$$
e_{0 a v e}=e_{\text {ave }}+\left(\kappa_{H_{2} S}-1\right) \cdot e_{H_{2} S a v e}
$$

ここで, $e_{a v e}$ は $\kappa_{H 2 S}=1$ の場合の合計環境評価点の平均 值, $e_{H 2 S a v e}$ は $\kappa_{H 2 S}=1$ の場合の環境因子 $\mathrm{H}_{2} \mathrm{~S}$ に対する環 境評価点の平均值である。 $W_{\text {ave }}, e_{\text {ave }}, e_{H 2 S a v e}$ は腐食減 量, 環境測定の結果から求まる. また e ouve は式 (2) から 求まる。 これらの值と式 (4) とから, 試験期間 $3 ， 6 ， 12$ ケ月毎に環境因子 $\mathrm{H}_{2} \mathrm{~S}$ に対する重み係数 $\kappa_{H 2 S}$ が求まる. 重々係数 $\kappa_{H 2 S}$ は暴露期間に依存しないものとして，これ らの平均值 $\kappa_{H 2 S}=4.3$ を得た.

Fig. 1 には試験サイト $B$ のデータについて $\kappa_{H 2 S}=4.3$ として改めて算出した合計環境評価点 $e_{0}$ と腐食減量 $W$ の関係（図中の も）も示したが，他の試験サイトでのそ れ（図中の○）と概ね一致している. 即ち, $\mathrm{H}_{2} \mathrm{~S}$ の環境 評価点 $e_{H 2 S}$ に重み係数 $\kappa_{H 2 S}=4.3$ を導入することによ り, 式 (2)は $\mathrm{H}_{2} \mathrm{~S}$ の効果の有無によらず腐食減量 $W$ と合 計環境評価点 $e$ (又は $e_{0}$ ) の関係を統一的に表すことが できる。

\section{$4 \cdot 3$ 腐食減量と暴露日数との関係の定式化}

Fig. 2 に全試験サイトの腐食減量 $W$ と暴露日数の平 方根 $\sqrt{d}$ との関係を示す. 腐食進行状態は試験サイト によって異なり，同一試験サイトにおいてもデータのバ ラッキは大きい. 図中に代表的な例として試験サイト $B$ と $D$ の腐食減量 $W$ と暴露日数の平方根 $\sqrt{d}$ との関係の 傾向を線図で示した。いずれの試験サイトの腐食減量 $W$ と暴露日数 $d$ の関係はいわゆる放物線則, すなわち式 (5) で表される.

$$
W=\beta_{1} \cdot \sqrt{d}+\beta_{2}
$$

$\beta_{1}, \beta_{2}$ は近似係数である.

上記のように, $\mathrm{Ag}$ の腐食減量 $W$ の暴露日数 $d$ への依 存性は放物線則に従うがデータのバラツキは大きい. 既

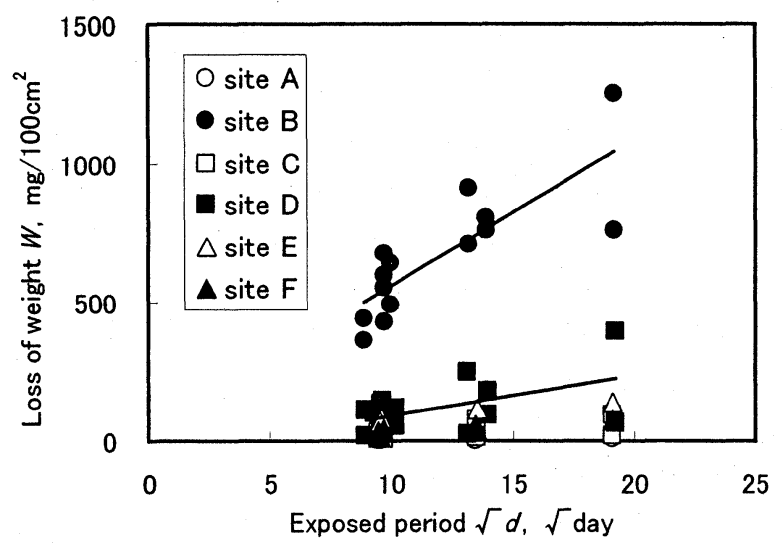

Fig. 2. Relationship between loss of weight and corrosion test period.
に述べたように, $\mathrm{Ag}$ の腐食減量 $W$ は環境の有害度（合 計環境評価点 $e$ ) の影響を受けるが, 合計環境評価点 $e$ は同一試験サイトでも年間を通して一定ではない. 合計 環境評価点 $e$ に年間を通して変化をもたらす要因は季節 要因, 即ち温度と湿度と考えられる。また温度と湿度は 同一季節でも屋内外で異なる：そこで各試験サイト毎に 環境を, (1) 屋内·夏, (2) 屋内·冬, (3) 屋外・夏, (4) 屋 外・冬の 4 つに分けて $W$ と $\sqrt{d}$ の関係を調べた，夏季 データは 5 月 25 日〜 12 月 12 日の 3 ケ月又は 6 ケ月間 に, 冬季データは 11 月 25 日〜 6 月 28 日の 3 ケ月又は 6 ケ月間に得られたものとした。 12 ケ月データは屋内, 屋外のみに分類した。

Fig. 3 に試験サイト $A$ と $B$ の $W$ と $\sqrt{d}$ の関係を上記 (1)〜4)の環境每に示した. 夏または冬に分類できない 1 年データは 3 ケ月と 6 ケ月データの傾向から外れるもの もあるが，いずれの場合も(1)（4)の環境每に $W$ と $\sqrt{d}$ の関係はほぼ直線的であり, 式 (5) で近似できる. 他の 試験サイトのデータも同様であった。

\section{$4 \cdot 4$ 環境評価点を用いた腐食寿命評価式}

以上のように腐食減量 $W$ は(1) (4)の環境每に暴露日 数 $d$ により式 (5) の放物線則で表すことができる. 即 ち, 式 (2) に打いて, 暴露日数 $d$ のみに依存する係数 $\alpha$ は暴露日数の平方根 $\sqrt{d}$ の一次式で表される. Fig. 4 に 試験期間 $3 ， 6 ， 12$ ケ月での暴露日数の平方根 $\sqrt{d}$ と式 (2) の係数 $\alpha$ の関係を示した，両者の関係は式 (6) で近 似できる.

$$
\alpha=\gamma_{1} \cdot \sqrt{d}+\gamma_{2}
$$

ここで, $\gamma_{1}, \gamma_{2}$ は近似係数であり, $\gamma_{1}=0.0012, \gamma_{2}=$ -0.0062 である. なお，試験期間 $3 ， 6,12$ ケ月の各期間 中の暴露日数は試験サイトや上記の (1) (4)の環境毎に若 干異なるので, 近似係数 $\gamma_{1}, \gamma_{2}$ を求めるに当り, 日数デ 一夕は各期間の平均日数を用いた. 式 (6) から式 (5) の 係数 $\beta_{1}$ と $\beta_{2}$ は式 (7) のように求まる.

$$
\begin{aligned}
& \beta_{1}=\left(e^{2}-64\right) \cdot \gamma_{1} \\
& \beta_{2}=\left(e^{2}-64\right) \cdot \gamma_{2}
\end{aligned}
$$

式 (7) を式 (5) に代入すれば, 腐食減量 $W$ と暴露日数 $d$, 合計環境評価点 $e$ (又は $e_{0}$ ) の具体的な関係を得る.

\section{$4 \cdot 5$ 腐食減量 $W$ の分布}

Fig. 5 に腐食減量の測定值 $W_{m}$ と式 (5) による推定值 $W_{e}$ の比 $W_{r}=W_{m} / W_{e}$ について順序統計により累積確率 $P$ の代表值を式 (8)で与え, その分布を示した (図中○).

$$
P\left(W_{r}\right)=\frac{i_{r}}{N+1}
$$

ここで, $i_{r}: W_{r}$ の昇順データ番号, $N:$ データ総数 であ る. 仮に同一環境において, 多数の曝露試験を行なった とすると, Fig. 5 に示す分布のデータが得られると考え られる. $W_{r}$ の平均值は $W_{r m}=1.39$ である.これは, 式 (5) が平均して実測值の $1 / 1.39$ 倍を推定していることを 意味する.すすなお，式 (5) に $A=W_{r m}=1.39$ を乗じた式 (9)を用いれば，腐食減量 $W$ をりり良く推定できる.

$$
W=A \cdot\left(e^{2}-64\right) \cdot\left(\gamma_{1} \cdot \sqrt{d}+\gamma_{2}\right)
$$



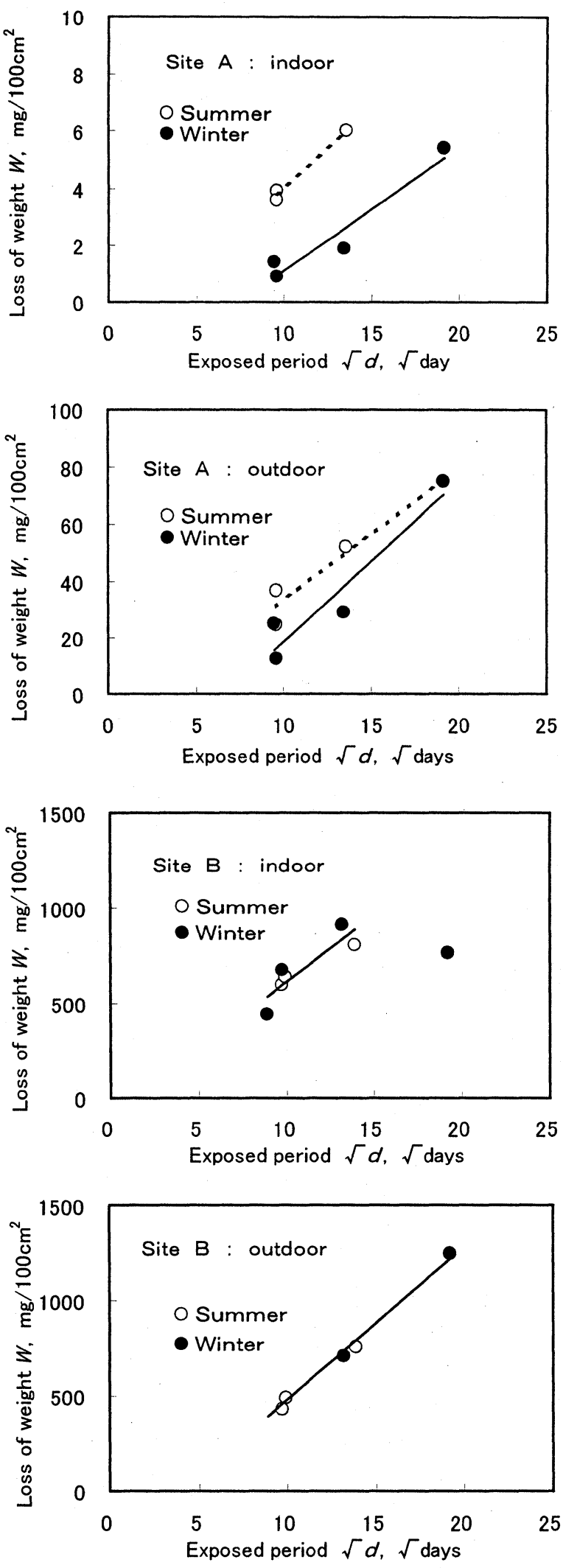

Fig. 3. Relationship between loss of weight and corrosion test period in site $\mathrm{A}$ and $\mathrm{B}$.

Fig. 5 には改めて式 (9) で求めた $W_{e}$ を用いて $W_{r}=$ $W_{m} / W_{e}$ を算出し, 累積確率 $P$ を求めて示した (図中心). 当然のことながら，式 (9) によれば式 (5) による場合 に比べて $W_{r}$ のばらつきは低減している。図から式 (9)に よる推定誤差の範囲は, 概ね $0.2 \sim 3.6$ 倍である. 具体

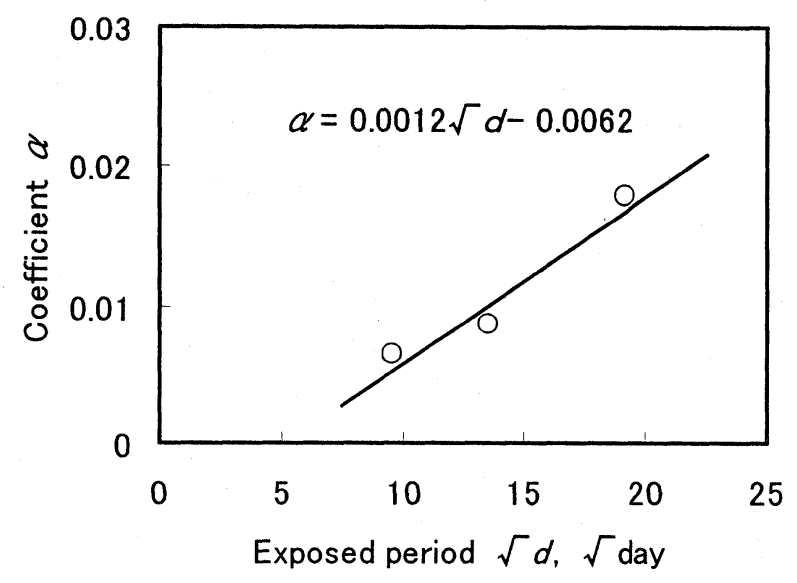

Fig. 4. Relationship between approximate coefficient $\alpha$ in Eq.(2) and exposed period.

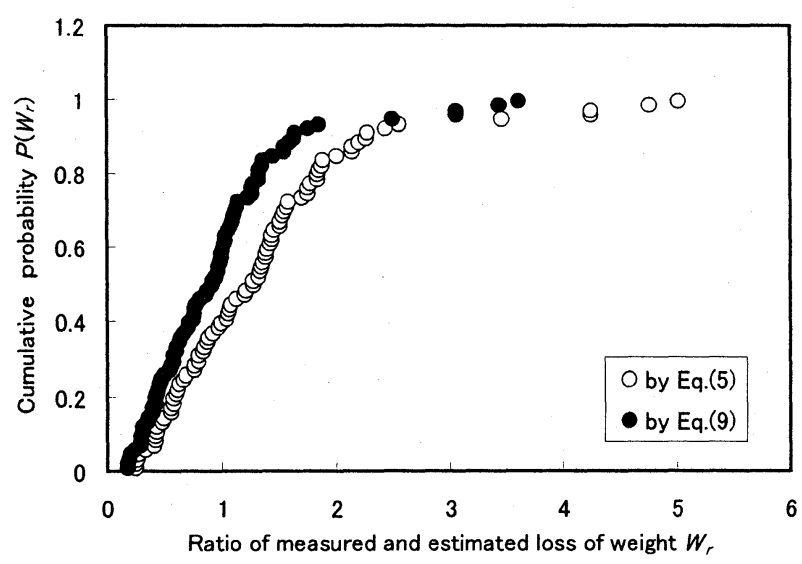

Fig. 5. Distribution of the ratio of measured and estimated loss of weight.

的に全ての腐食減量実測値 $W_{m}$ と式 (9) による推定値 $W_{e}$ を比較して Fig. 6 に示す. Fig. 5 での推定誤差の範 囲 $0.2 \sim 3.6$ 倍に対応して, Fig. 6 では腐食減量の実測 值 $W_{m}$ に対する推定値 $W_{e}$ の幅は約 1 けたである.

\section{$4 \cdot 6$ 基準化腐食減量 $W_{n}$ による腐食寿命評価}

前項では, 腐食減量 $W$ が合計環境評価点 $e$ (又は $e_{0}$ ) を用いて式 (9) により評価できることを示した。式 (9) を用いると, 任意の合計環境評価点 $e_{a}$ での腐食減量 $W_{a}$ は式 (10) によって， ある特定の合計環境評価点 $e_{n}$ での 腐食減量 $W_{n}$ に換算することができる。これを基準化腐 食減量と呼ぶ。

$$
W_{n}=\frac{W_{a}}{W\left(e_{a}\right)} \cdot W\left(e_{n}\right)
$$

ここで，W( $\left.e_{a}\right), W\left(e_{n}\right)$ はそれぞれ合計環境評価点が $e_{a}$, $e_{n}$ の場合の式 (9) による腐食隇量の推定值である. 即 ち, $i(\neq 1)$ なる環境（合計環境評価点 $e_{i}$ ) で測定され た限られた数 $j(\neq 1)$ の腐食減量データ $W_{i, j}$ は式 (10) に よって，ある同一の $k$ なる環境 (合計環境評価点 $e_{k}$ ) で の多数 $\left(\Sigma_{j}\right)$ の腐食減量データ $W_{k}, \Sigma_{j j}$ として扱うことがで きる。

Fig. 7 に, Fig. 2 に示した合計環境評価点が異なる $(e=$ 10 ～175）全ての腐食減量データ（図中○）を示すと共 


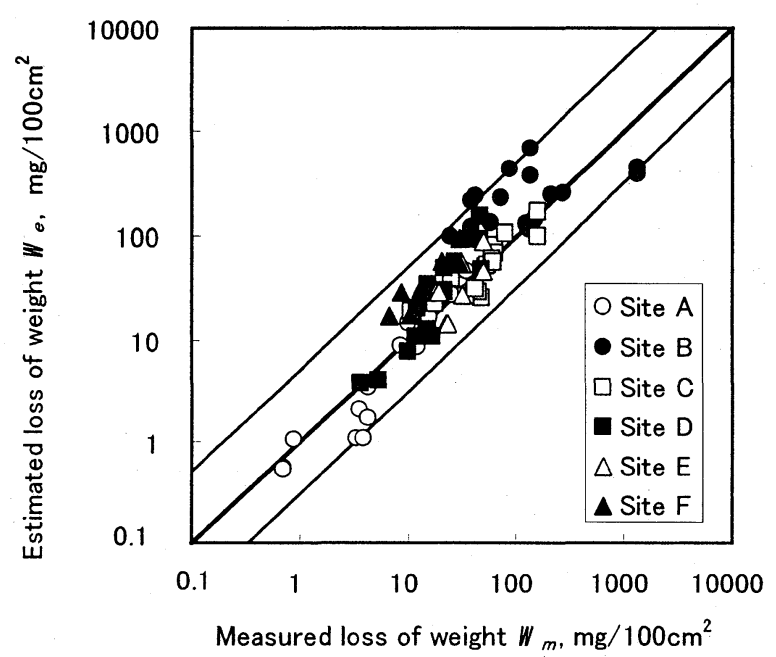

Fig. 6. Comparison between measured and estimated loss of weight.

に，これらのデータを，式(10)を用い，例として合計 環境評価点 $e_{n}=65$ の場合の基準化腐食減量 $W_{n}$ と曝露 日数 $d$ との関係を示した（図中の）。併せて，同合計環 境評価点 $\left(e_{n}=65\right)$ のでの式 (9) の腐食減量 $W$ と曝露日 数 $d$ との関係も示した (図中実線). $\mathrm{Ag}$ の腐食減量 $W$ と暴露期間 $d$ との関係（図中○）は合計環境評価点 $e$ に 大きく依存して 3 桁程度の範囲にばらつくが，基準化腐 食減量 $W_{n}$ （四中）のばらつきは 1 けた程度に収まる。 $\mathrm{Ag}$ の腐食寿命評価には基準化腐食減量 $W_{n}$ を用いるこ と，すなわち，式 (9) によって腐食寿命を評価すること が有効である。

Fig. 8 に合計環境評価点が $e=65$ の場合の基準化腐食 減量 $W_{n}$ と曝露日数 $d$ との関係（図中○）を，実際に合 計環境評価点が $e=65$ の試験サイト Cの冬季の屋外に 打ける腐食減量 $W$ の実測データ（四中）と比較して示 した。実測データ（図中の）は同一の合計環境評価点で の多数の基準化腐食減量データ（図中○）のばらつきの 範囲に含まれる，すなわち， は本来，○のように分布 する腐食減量データの内の一つととして測定されたもの と考えることができる.

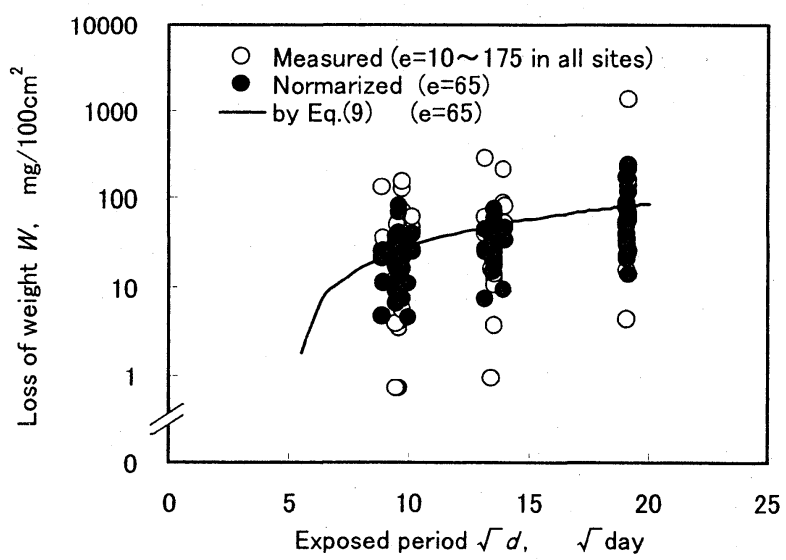

Fig. 7. Comparison between measured and normalized loss of weight.

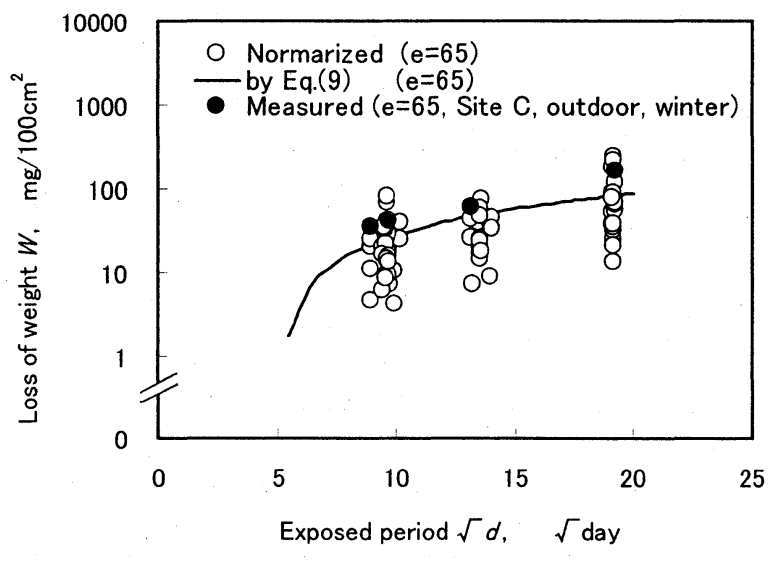

Fig. 8. Comparison between normalized and measured loss of weight.

\section{$4 \cdot 7$ 実用的な腐食寿命評価法}

Fig. 5 では, 腐食減量の実測值と推定值の比 $W_{r}(=$ $\left.W_{m} / W_{e}\right)$ の分布を示した。これは取りも直さず基準化腐 食減量 $W_{n}$ の分布であり, Fig. 9 に改めてこれを図示し, 併せて式 (11)，(12)，(13) の它れぞれ正規分布，2 母数 ワイブル分布, 3 母数ワイブル分布を当てはめた結果を 線図で示した。

$$
F(x)=\int_{-\infty}^{x} \frac{1}{\sigma_{1} \sqrt{2 \pi}} \cdot \exp \left\{-\frac{\left(x-\mu_{1}\right)^{2}}{2 \sigma_{1}^{2}}\right\} d x
$$

ここで, $F(x)$ : 累積確率, $\mu_{1}$ : 平均 $(=1), \sigma_{1}$ : 標準偏 差 $(=0.70)$ である.

$$
G(x)=1-\exp \left\{-\left(\frac{x}{\sigma_{2}}\right)^{m_{2}}\right\}
$$

ここで, $G(x)$ : 累積確率, $m_{2}$ : 形状母数 $(=1.82) \sigma_{2}$ : 尺 度母数 $(=1.10)$ である.

$$
H(x)=1-\exp \left\{-\left(\frac{x-\mu_{3}}{\sigma_{3}}\right)^{m_{3}}\right\}
$$

ここで, $H(x)$ : 累積確率, $m_{3}$ : 形状母数 (= 1.28), $\mu_{3}$ : 位置母数 $(=0.15), \sigma_{3}$ ： 尺度母数 $(=0.92)$ である.

Fig. 9 から基準化腐食減量 $W_{n}$ の分布形態が明らかに なった，基準化腐食減量 $W_{n}$ は 2 母数ワイブル分布，ま たは 3 母数ワイブル分布に適合する. 実機部品で腐食寿 命を診断するには，基準化腐食減量 $W_{n}$ の分布を考慮し て安全側に評価することが必要である，安全裕度を定め るには，材料の腐食特性や当該材料が使用される装置， 部品に要求される信頼性などを含め総合的な検討が必要 であるが，ここでは分布のみを考慮した安全側の寿命評 価線図の例を示す。

Fig. 10 に, 合計環境評価点 $e=14.5$ の場合について, 基準化腐食減量 $W_{n}$ が 3 母数ワイブル分布に従うとして, 式 (9) の腐食寿命評価式を基に定めた信頼区間 90\%を実 線と点線で示した。寿命評価線図として信頼区間 90\%の 上限側（図中の実線）を使用すれば，合計環境評価点 $e$ = 14.5 の環境での腐食減量の $95 \%$ を含む寿命（暴露日 数）を予測することができる。なお，基準化腐食減量 $W_{n}$ は合計環境評価点 $e$ に依存しないとしている。 


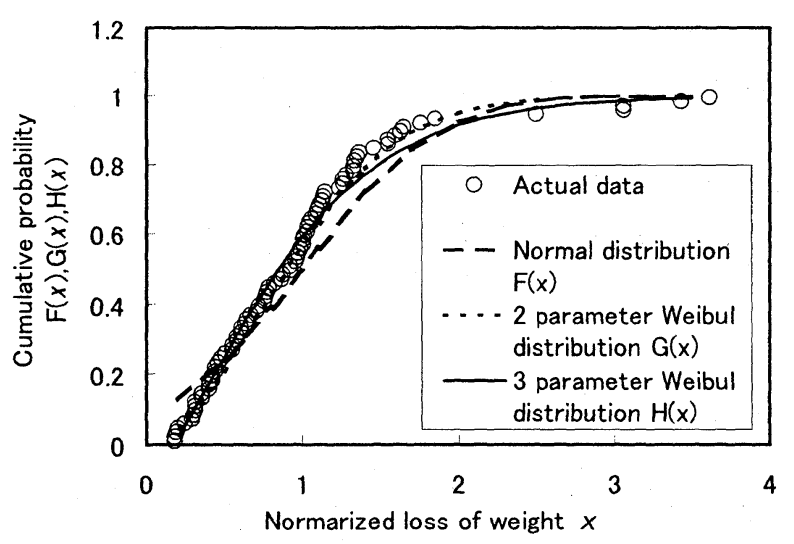

Fig. 9. Distribution of normalized loss of weight.

\section{5 結言}

電気・電子部品材料として多用され，大気中で使用さ れる $\mathrm{Ag}$ について, 大気腐食に関するフィールドデータ を解析し, 環境測定から得られるデータとの関連性を検 討し, 以下の知見を得ると共に, 実用的な腐食寿命評価 法を提案した.

(1) $\mathrm{Ag}$ の大気腐食における腐食減量 $W$ と環境測定か ら得られる合計環境評価点 $e$ との間には定量的な関係が あり, 腐食減量 $W$ は合計環境評価点 $e$ の二次式で表わ される。

(2) $\mathrm{Ag}$ の大気腐食への影響が大きい $\mathrm{H}_{2} \mathrm{~S}$ を含む環境 では, 合計環境評価点 $e$ の算出に当り重み係数 $\kappa_{H 2 S}=$ 4.3 を導入することにより, $\mathrm{H}_{2} \mathrm{~S}$ の有無に拘わらず統一的 に腐食減量 $W$ と合計環境評価点 $e$ の定量的な関係が得 られる。

(3) $\mathrm{Ag}$ の大気腐食に打ける腐食減量 $W$ の暴露日数 $d$ への依存性は放物線則で表現でき，また放物線則の係数 は合計環境評価点 $e$ の二次式で表現でき, 腐食寿命は環

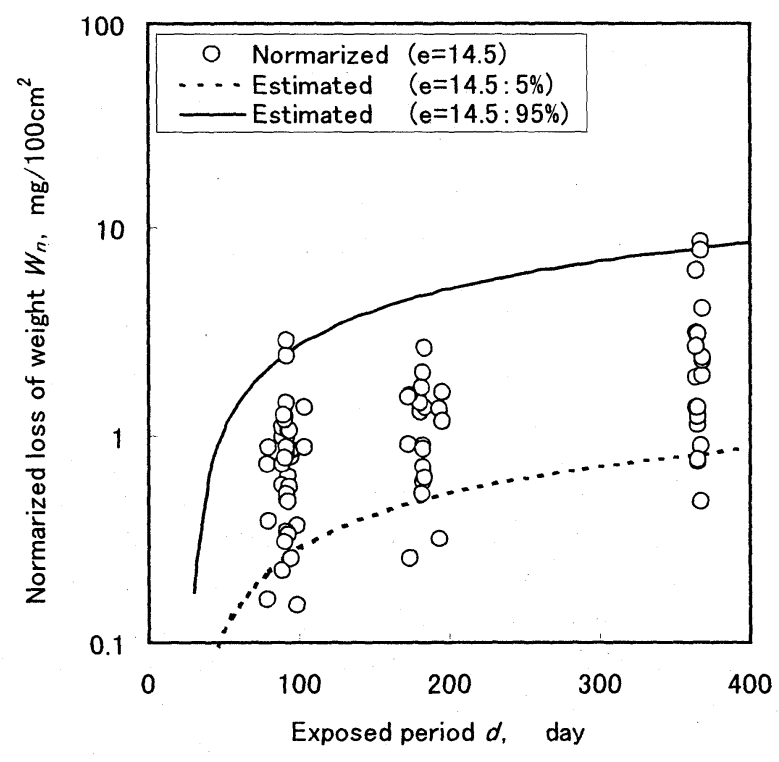

Fig. 10. Example of practical life assessment curve.

境評価を通して当該環境の合計環境評価点 $e$ を求めるこ とのみにより評価できる。

(4) $\mathrm{Ag}$ の大気腐食に打ける腐食減量 $W$ の分布はワイ ブル分布に適合する，本分布を考慮し，実用的な腐食寿 命評価線図が設定できる。

\section{参 考 文 献}

1）藤堂洋子，木村和成，兼平勝己, 深倉壽一, 材料と環境 (投稿中).

2 ）屋外暴露試験方法通則 JIS-Z-2381.

3 ) (社) 電子情報技術産業協会, 産業用情報処理 - 制御機器設 置環境基準 JEIDA-63_2000. 